\title{
Unveiling Indonesian Pre-Service Teachers' Perceived Competencies and Readiness for Online English Language Teaching: A Mixed Methods Study
}

\author{
Daflizar \\ English Education Department, Institut Agama Islam Negeri Kerinci, Indonesia \\ Toni Indrayadi \\ English Education Department, Institut Agama Islam Negeri Kerinci, Indonesia \\ Yoki Irawan \\ English Education Department, Institut Agama Islam Negeri Kerinci, Indonesia
}

\begin{abstract}
There has been a great deal of research into teacher readiness for online language teaching conducted in many parts of the world. However, scarce inquiry on this topic has been published in the Indonesian context. The purpose of this study was twofold: (1) to investigate Indonesian EFL pre-service teachers' perceptions of their technological, pedagogical, and evaluation skills in online language teaching, and (2) to explore their perceptions of online English language teaching. The study employed a mixed methods research approach. The quantitative data were collected using a questionnaire from 92 pre-service teachers majoring in English Education at a state Islamic institute in Jambi province and the qualitative data were collected through WhatsApp messenger from six of the participants. The data obtained through the questionnaire were analyzed using descriptive statistics and the qualitative data were analyzed using content analysis. The results showed that the participants had positive perceptions of their technological, pedagogical, and evaluation skills in online English language teaching. However, the qualitative data demonstrated that the participants had a strong inclination toward classroom face-to-face teaching rather than online teaching for a number of reasons, indicating that they were not ready for online English language teaching. Some practical suggestions for the EFL teacher training programs in Indonesian tertiary education institutions are given.
\end{abstract}

Index Terms-pre-service teachers, perceived competencies, readiness, online English language teaching, the Indonesian context

\section{INTRODUCTION}

The recent worldwide outbreak of Coronavirus Disease (COVID-19) means unprecedented changes in many aspects of life, including education. The need for social distancing has triggered educational institutions to change the basic way they work. Many schools, colleges, and universities have abruptly adopted online teaching in place of face-to-face classroom teaching. This sudden shift may cause ineptness for many teachers since they are not used to this modality of teaching. In Lamie's (2005) educational innovation classifications, this imposed shift constitutes a power-coercive unintentional innovation, a kind with one of the lowest possibilities of being successful. Coupled with the proliferation of the internet and computers, nevertheless, trends in online teaching and learning will likely continue. Relevant research highlights the demands and shortcomings of online teaching and learning. According to Koehler and Mishra (2005), online teaching entails an integrated knowledge of content, technology, and pedagogy beyond that anticipated by teachers who teach only face-to-face courses. Baralt, Gurzynski-Weiss, and Kim (2016) argued that online learning may be less effective than face-to-face classroom learning because students are less engaged. Although educators seem to recognize the prominence of ICT in schools, they continue to encounter problems during the process of embracing the technologies (Balanskat, Blamire, \& Kefala, 2006). Many teachers do not know how to incorporate educational technology into their curriculum (Townsend, 2017) and have problems in finding suitable activities that can stimulate student interest and in marking student assignments (Todd, 2020).

Since online teaching demands different roles of the teacher, it inevitably prompts the need for new teaching approaches and competencies (Hampel \& Stickler, 2005; Ko, \& Rossen, 2017; Wray, Lowenthal, Bates, \& Stevens, 2008). Online language teaching competencies are crucial since the focus is on instructional time and space, online management techniques, and the ability to involve learners through online communication (Easton, 2003) and, particularly at the lower level, there is a 'need to focus on the form of interaction as well as the content' (Hampel \& Stickler, 2005, p. 312). The teacher is expected to become a facilitator (Frese, 2006; Jaffee, 2003) and is required to 
have discussion and learning activity management skills to engage learners and ensure they are interacting adequately with the content (Frese, 2006). Thus, to engage effectively and critically in technology-associated teaching issues, it is essential to make clear the key competencies of language teachers (Chapelle \& Hegelheimer, 2004).

Many studies have been conducted on the issue of teachers' readiness for online teaching. However, very few have investigated the readiness of pre-service teachers to teach online language teaching. Since pre-service teachers are prepared to face the reality of teaching in near future, understanding their readiness is important to identify directions that could increase the likelihood of successful online teaching. Moreover, the findings of this study could be used to put recommendations forward to teacher education institutions for better instruction. Therefore, the following research questions guide the present study: 1) What are Indonesian EFL pre-service teachers' perceptions of their technological, pedagogical, and evaluation competencies in online English language teaching? and 2) What are their perceptions of online English language teaching?

\section{LITERATURE REVIEW}

\section{A. Online Teaching Competencies}

Researchers have attempted to define the competencies required for online teaching. Williams (2003) proposed a framework consisting of four general competencies; they are (1) communication and interaction, (2) management and administration, (3) technology, and (4) learning and instruction. The communication and interaction competencies consist of several general competencies such as collaboration/teamwork skills, interpersonal communicative skills, English proficiency, questioning skills, negotiation skills, etc. The management and administration competencies include, among others: organizational, planning, consulting, and personal organization skills, and knowledge of support services. The technological competencies include knowledge of basic technology, technology access, and multimedia and software skills. Lastly, the learning and instruction competencies consist of knowledge of the distance learning field and some other competencies such as feedback, facilitation (discussion), presentation, evaluation, and needs assessment skills (p. 51).

Concerning language courses, Hampel and Stickler (2005) identified seven key competencies that range from a lower level to higher-level skills a teacher should have. These include computer literacy, the ability to use specific software applications, understanding of the possibilities and constraints of specific applications, online socialization, communicative competence, creativity and choice, the ability to develop an individual teaching style, make the most of the media and materials, build a connection with the students, and use the resources creatively to foster active and communicative language learning. Compton (2009) proposed a framework that consists of three major sets of online teaching skills: a) technological; b) pedagogical; and c) evaluation. The technological skills are related to the knowledge and ability to handle hardware and software issues. The pedagogical skills have to do with the knowledge and ability to carry out and facilitate teaching and learning activities. Lastly, the evaluation skills refer to the analytical ability to assess the tasks and overall course and make necessary modifications to ensure language learning objectives are met. All these skills are organized into three levels of expertise: novice, proficient, and expert. According to Compton (2009), these levels are not absolute but rather a continuum of expertise.

\section{B. Previous Studies}

To date, many studies have been done to investigate teachers' readiness for online teaching. Downing and Dyment (2013), for example, conducted a study on teacher educators' readiness, preparation for, and perceptions of preparing pre-service teachers in an entirely online setting. The results revealed that the teachers regarded online teaching timeconsuming, and those new to online teaching felt a lack of readiness to teach online and needed technical and pedagogical support as well as time-management strategies. Lichoro (2015) explored the experiences of Iowa Community College faculty members who shifted from the face-to-face classroom to online teaching. The findings showed that making the transition from face-face teaching to online instruction experience is considerably timeconsuming and changes the faculty's role and teaching responsibilities. Most of the participants did not feel adequately ready for teaching online. Gay (2016) assessed online teacher e-learning readiness before, during, and after course delivery. The results indicated that online teachers urgently needed online help desk services. In a study with elementary and secondary teachers who were enrolled in the Pangasinan State University, Ventayen (2018) found that the teachers had a positive attitude and the majority of the respondents were ready for online teaching. Grimshaw, Cardoso, and Collins (2017) found that the majority of language teachers were open to engaging their students in mobile-assisted language learning, but they still worried about the drawback of the style of learning.

Dashtestani (2013) explored Iranian EFL teachers' attitudes toward the implementation of mobile-assisted language learning. The result demonstrated that although the teachers had positive attitudes toward the use of mobile phones for language learning and teaching, they faced a number of constraints such as low-speed internet connection, and students may not use their mobile phones for academic purposes. Todd (2020) investigated the perceptions of 52 English language teachers of the alteration from the classroom to online teaching at one Thai university. The findings showed that in the beginning, teachers rated many of the problems as serious, but they quickly found solutions. However, problems remained with identifying suitable stimulating activities and marking student assignments. Among the 
benefits of online teaching mentioned by the participants were flexibility, independence, saving travel expenses, etc. On the other hand, the participants found difficulties in attaining some English language objectives and in evaluating student reactions.

Perifanou, Economides, and Tzafilkou (2021) investigated Greek teachers' perceptions of their digital skills for performing their teaching and professional duties during the Covid-19 pandemic. The findings showed that the teachers generally used digital tools for many educational purposes, including finding, evaluating, and developing resources, teaching, self-study, assessing students, and interacting as well as communicating with their students. On the other hand, they seldom used digital tools for some other teaching activities such as giving feedback and doing final evaluations of the students.

Although abundant studies related to online teaching have been undertaken around the world, scant research on this issue has been published in the Indonesian context (Hadiyanto, Mukminin, Makmur, Hidayat, \& Failasofah, 2013; Champa, Rochsantiningsih, \& Kristiana, 2019). Each of these studies had a different focus from the present study. Hadiyanto et al. (2013) examined the readiness of 47 English lecturers for internet use in English teaching and learning at the university level. Champa et al. (2019) investigated the factors of teachers' readiness to integrate ICT into their teaching. This gives the present study significant importance as it attempted to fill the gaps. It investigated the perceptions of Indonesian EFL pre-service teachers in terms of their technological, pedagogical, and evaluation competencies and explored their perceptions of online English language teaching.

\section{METHOD}

\section{A. Research Design}

To answer the research questions, both quantitative and qualitative methods were employed in the present study. According to Ivankova, Creswell, and Stick (2006), when used in combination, the quantitative and qualitative methods enhance each other and allow the researcher to exploit the strengths of each and embark on a vigorous analysis of the data for more meaningful findings.

\section{B. Participants}

This study involved 92 pre-service teachers majoring in English Education at a state Islamic institute in Jambi province, Indonesia. The participants comprised 20 males and 72 females and were in the fourth or final year of their study. All 92 participants completed the questionnaire in the quantitative phase and 6 of them were selected for the qualitative phase of the study.

\section{Research Instruments}

In the quantitative part of the study, a questionnaire was used to collect the data on the pre-service teachers' perceptions of online language teaching competencies. The questionnaire was developed and adapted based on a framework for online language teaching skills proposed by Compton (2009). It consisted of 30 items focusing on three major sets of online language teaching competencies: technological skills, pedagogical skills, and evaluation skills. The technological skill section consists of 10 items focusing on teachers' knowledge and skills of technology in online language teaching. The pedagogical skill section comprises 14 items exploring teachers' knowledge and skills of pedagogy of online language teaching. The last section, evaluation, focuses on teachers' knowledge and ability in evaluating online language teaching. The respondents were asked to rate their answers on a five-point scale from 'very poor' to 'very good'. The internal consistency of the questionnaire was measured and found very high, with a Cronbach alpha coefficient of .97. The questionnaire was validated by three experts in the field of English language teaching. All of the validators have doctoral degrees in English language teaching. Before being used for the data collection, the questionnaire was tried out to two pre-service teachers to collect feedback about the wording of the questionnaire. According to Dörnyei (2010), a try-out of a questionnaire allows the researcher "to collect feedback about how the instrument works and whether it performs the job it has been designed for" (p. 53). The construct validity of the questionnaire was also established. The determination of the adequacy of the exploratory factor analysis (EFA) was performed through the analysis of the Kaiser-Meyer-Olkin (KMO) measure and Bartlett's test. If the result of Bartlett's test is $<0.05$, factor analysis can be used. The KMO statistics range from 0 to 1 , with values closer to 1 denoting greater adequacy of the factor analysis (KMO $\geq 0.6$ low adequacy, $\mathrm{KMO} \geq 0.7$ medium adequacy, KMO $\geq 0.8$ high adequacy, $\mathrm{KMO} \geq 0.9$ very high adequacy). The analysis showed that Bartlett's test score of the questionnaire was 0.00 with a KMO score of 0.85 .

In the qualitative part, the data were collected using Whatsapp messenger. The 6 participants were asked several questions regarding their perceptions of online language teaching.

\section{Data Collection and Analysis}

The questionnaire was distributed online using Microsoft forms. Before the administration of the questionnaire, the participants were informed that the outcomes of the study would provide a better understanding of their preparedness to teach English language courses online. They were requested to complete the questionnaire as honestly as they could. The participants were also informed that their identities would be kept confidential and anonymous. The students who 
were chosen for the qualitative phase were contacted if they agreed to participate. To avoid miscommunication, both the questionnaire and interview questions were written in Bahasa Indonesia.

The questionnaire data were analyzed using descriptive statistics, in which the percentages of students' responses were calculated. The interview results were analyzed using content analysis.

\section{FINDINGS}

\section{A. Perceptions of Technological, Pedagogical, and Evaluation Skills}

Table 1 presents the percentages of participants' responses related to their technological skills in online language teaching. As seen in the table, most of the responses congregate in the 'OK' and 'Good' categories of the scale. Specifically, there were 6 out of 10 items in the 'OK' category that were chosen by more than $40 \%$ of the participants, and 3 items were chosen by more than $40 \%$ of the participants in the 'Good' category. The first three skills rated the most by the participants in the 'OK' category include: 'understanding of the constraints and possibilities of different software' (51.09\%), 'ability to deal with constraints and possibilities of different software' (51.09\%), ability to identify features of different software' (46.74\%), and 'creativity in using and adapting for online language learning tasks' (45.65\%). In the 'Good' category, the skills include: 'ability to use a range of software' (43.48 \%), 'ability to choose suitable technology to match online language learning task' (43.48\%), and 'creativity in using and adapting for online language learning tasks' (41.30\%). On the contrary, there were two skills rated by more than $40 \%$ in the 'Poor' category of the scale. They were: 'ability to create basic Web pages' $(40.22 \%)$, and 'ability to construct interactive Web pages' $(40.22 \%)$.

TABLE 1

PRE-SERVICE TEACHERS' PERCEPTIONS OF THEIR TECHNOLOGICAL SKILLS

\begin{tabular}{|c|c|c|c|c|c|}
\hline Skills & $\begin{array}{l}\text { Very poor } \\
(\%)\end{array}$ & $\begin{array}{l}\text { Poor } \\
(\%)\end{array}$ & $\begin{array}{l}\mathrm{OK} \\
(\%)\end{array}$ & $\begin{array}{c}\text { Good } \\
(\%)\end{array}$ & $\begin{array}{l}\text { Very good } \\
(\%)\end{array}$ \\
\hline Your ability to use a range of software & 0 & 7.61 & 42.39 & 43.48 & 6.52 \\
\hline Your ability to identify features of different software & 0 & 18.48 & 46.74 & 31.52 & 3.26 \\
\hline $\begin{array}{l}\text { Your understanding of the constraints and possibilities of different } \\
\text { software }\end{array}$ & 2.17 & 22.83 & 51.09 & 21.74 & 2.17 \\
\hline $\begin{array}{l}\text { Your ability to choose suitable technology to match online } \\
\text { language learning tasks }\end{array}$ & 0 & 9.78 & 35.87 & 43.48 & 10.87 \\
\hline $\begin{array}{l}\text { Your ability to deal with constraints and possibilities of different } \\
\text { software }\end{array}$ & 2.17 & 13.79 & 51.09 & 26.09 & 3.26 \\
\hline Your ability to create basic Web pages & 14.13 & 40.22 & 32.61 & 11.96 & 1.09 \\
\hline Your ability to troubleshoot basic browser problems & 7.61 & 34.78 & 38.04 & 17.39 & 2.17 \\
\hline $\begin{array}{l}\text { Your creativity in using and adapting for online language learning } \\
\text { tasks }\end{array}$ & 1.09 & 3.26 & 45.65 & 41.30 & 8.70 \\
\hline Your ability to construct interactive Web pages & 8.70 & 40.22 & 44.57 & 5.43 & 1.09 \\
\hline Your knowledge of basic programming language & 10.87 & 34.78 & 38.04 & 15.22 & 1.09 \\
\hline
\end{tabular}

Regarding pedagogical skills, it is evident that the majority of the participants had positive perceptions. As shown in Table 2 below, the participants' responses also clustered in the 'OK' and 'Good' categories of the scale. Specifically, there were 13 out of 14 items that were chosen by more than $40 \%$ of the participants in the 'OK' category and one item in the 'Good' category. The first six highest-rated items in the 'OK' category were:

- ability to facilitate communicative competence and online interaction (54.35\%)

- ability to apply language learning theories for online language learning (50.00\%)

- creativity in using and adapting materials to create new online language materials and tasks to facilitate communicative competence and online interaction $(48.91 \%)$

- knowledge of strategies for online language assessment (47.83\%)

- creativity in facilitating online socialization and community building (47.83\%)

- ability to do an intuitive and integrated assessment of language learning (47.83\%) 
TABLE 2

PRE-SERVICE TEACHERS' PERCEPTIONS OF THEIR PEDAGOGICAL SKILLS

\begin{tabular}{|c|c|c|c|c|c|}
\hline Skills & $\begin{array}{l}\text { Very poor } \\
(\%)\end{array}$ & $\begin{array}{c}\text { Poor } \\
(\%)\end{array}$ & $\begin{array}{l}\text { OK } \\
(\%)\end{array}$ & $\begin{array}{c}\text { Good } \\
(\%)\end{array}$ & $\begin{array}{l}\text { Very good } \\
(\%)\end{array}$ \\
\hline $\begin{array}{l}\text { Your knowledge of strategies for online community building and } \\
\text { socialization }\end{array}$ & 7.61 & 18.48 & 43.48 & 25.00 & 5.43 \\
\hline $\begin{array}{l}\text { Your knowledge of strategies to facilitate communicative } \\
\text { competence and online interaction }\end{array}$ & 6.52 & 22.83 & 39.13 & 27.17 & 4.35 \\
\hline $\begin{array}{l}\text { Your knowledge of language learning theories for online language } \\
\text { learning }\end{array}$ & 1.09 & 11.96 & 45.65 & 34.78 & 6.52 \\
\hline $\begin{array}{l}\text { Your knowledge of curriculum design framework for online } \\
\text { language learning }\end{array}$ & 5.43 & 21.74 & 41.30 & 28.26 & 3.26 \\
\hline Your knowledge of strategies for online language assessment & 1.09 & 17.39 & 47.83 & 29.35 & 4.35 \\
\hline Your ability to foster online community and socialization & 2.17 & 20.65 & 43.48 & 28.26 & 5.43 \\
\hline $\begin{array}{l}\text { Your ability to facilitate communicative competence and online } \\
\text { interaction }\end{array}$ & 5.43 & 15.22 & 54.35 & 23.91 & 1.09 \\
\hline $\begin{array}{l}\text { Your ability to choose suitable materials to match online language } \\
\text { learning tasks }\end{array}$ & 1.09 & 8.70 & 41.30 & 40.22 & 8.70 \\
\hline $\begin{array}{l}\text { Your ability to apply language learning theories for online } \\
\text { language learning }\end{array}$ & 2.17 & 10.87 & 50.00 & 31.52 & 5.43 \\
\hline $\begin{array}{l}\text { Your ability to apply curriculum design framework for online } \\
\text { language learning }\end{array}$ & 1.09 & 23.91 & 45.65 & 26.09 & 3.26 \\
\hline $\begin{array}{l}\text { Your ability to assess language learning using different assessment } \\
\text { methods }\end{array}$ & 5.43 & 18.48 & 42.39 & 31.52 & 2.17 \\
\hline $\begin{array}{l}\text { Your creativity in using and adapting materials to create new } \\
\text { online language materials and tasks to facilitate communicative } \\
\text { competence and online interaction }\end{array}$ & 2.17 & 19.57 & 48.91 & 28.26 & 1.09 \\
\hline $\begin{array}{l}\text { Your creativity in facilitating online socialization and community } \\
\text { building }\end{array}$ & 0 & 22.83 & 47.83 & 28.26 & 1.09 \\
\hline $\begin{array}{l}\text { Your ability to do an intuitive and integrated assessment of } \\
\text { language learning }\end{array}$ & 3.26 & 22.83 & 47.83 & 25.00 & 1.09 \\
\hline
\end{tabular}

Like in the two skills above, the majority of the participants' responses as regards their evaluation skills also clustered in the 'OK' and 'Good' categories of the scale. In the 'OK' category, all six items were chosen by more than $40 \%$ of the participants (see Table 3 ).

TABLE 3

PRE-SERVICE TEACHERS' PERCEPTIONS OF THEIR EVALUATION SKILlS

\begin{tabular}{|c|c|c|c|c|c|}
\hline Skills & $\begin{array}{l}\text { Very poor } \\
(\%)\end{array}$ & $\begin{array}{l}\text { Poor } \\
(\%)\end{array}$ & $\begin{array}{l}\mathrm{OK} \\
(\%)\end{array}$ & $\begin{array}{c}\text { Good } \\
(\%)\end{array}$ & $\begin{array}{l}\text { Very good } \\
(\%)\end{array}$ \\
\hline Your basic knowledge of task evaluation & 1.09 & 8.70 & 51.09 & 31.52 & 7.61 \\
\hline Your basic knowledge of course evaluation & 2.17 & 22.83 & 44.57 & 28.26 & 2.17 \\
\hline $\begin{array}{l}\text { Your ability to evaluate online language learning tasks based on } \\
\text { one or more frameworks and to modify tasks accordingly }\end{array}$ & 1.09 & 21.74 & 48.91 & 26.09 & 2.17 \\
\hline $\begin{array}{l}\text { Your ability to evaluate online language courses based on one or } \\
\text { more frameworks and to modify components accordingly }\end{array}$ & 1.09 & 29.35 & 43.48 & 21.74 & 4.35 \\
\hline $\begin{array}{l}\text { Your ability to do an intuitive and integrative evaluation of online } \\
\text { language learning tasks based on one or more frameworks }\end{array}$ & 1.09 & 27.17 & 45.65 & 23.91 & 2.17 \\
\hline $\begin{array}{l}\text { Your ability to do an intuitive and integrated formative evaluation } \\
\text { of online language courses }\end{array}$ & 2.17 & 26.09 & 43.48 & 22.83 & 5.43 \\
\hline
\end{tabular}

\section{B. Perceptions of Online English Language Teaching}

In the qualitative phase of the study, the participants were asked several questions to explore their perceptions of online English language teaching. The first question asked was which mode of teaching the participants would choose between classroom face-to-face teaching and online teaching. The results revealed that all the respondents preferred classroom face-to-face teaching to online teaching. When asked the reasons for the choice, R1 and R2 commented that with the classroom teaching, the teacher could explain the lesson more freely and the teaching and learning process could be more focused. R1 said:

Karena kalau mengajar di ruang kelas lebih leluasa untuk menjelaskan dan siswa bisa lebih faham dan fokus dalam mendengarkan materi dan juga bisa langsung mempraktekkan apa yg dipelajari. Sedangkan online, selain waktu yg terbatas.. dan signal yg kadang memburuk.. juga siswa sulit untuk mengerti karena kalau di online susah untuk menjelaskan materi secara spesifik.

(It is because classroom teaching allows the teacher to freely explain the lesson and the students could understand more and are concentrated to listen to the teacher talk, and they can also practice what they have just learned. Meanwhile, in online teaching, time is limited.. the network is sometimes bad.. Also, the students can hardly understand because the teacher cannot explain the lesson specifically). 
For R3 and R5, classroom teaching is preferable because it allows direct interaction between the teacher and students. R3 commented, 'Karena dengan belajar di ruang kelas kita bisa berinteraksi langsung dengan siswa, kita juga bisa tau kemampuan siswa yang sebenarnya, dan siswa jadi lebih mudah mengerti saat belajar secara langsung di kelas' (Because by learning in the classroom, we can interact person to person with the students, we can also know the true ability of the students, and the students can understand more easily through classroom learning). R5 added, ' ... juga mempermudah guru dalam menyampaikan materi-materi pembelajaran dgn penggunaan media pembelajaran' (...also, it is easier for the teacher to deliver learning materials using learning media).

For R4, classroom teaching is preferable because 'the teacher can easily control the students and apply preferred teaching strategies.' A similar comment was expressed by R6, saying, 'Lebih mudah menyampaikan materi... lebih mudah mengontrol siswa' (It is easier to deliver the materials... it is easier to control the students).

The second interview question asked what constraints the respondents would face in online teaching. Almost all respondents agreed that a bad network is a major constraint they would find. Besides, some respondents believed that with online teaching it is difficult for the teacher to control the students and explain the materials in detail. R5 said:

Pada sistem belajar online ini akan sulit pemantauan siswa dan controlling saat proses belajar. Materi yang di sampaikan pun tidak bisa maksimal... sehingga murid akan sulit memahami materi pembelajaran dan biasanya akan sulit juga bagi siswa untuk mengerjakan tugas yg diberikan.

(In online teaching, it is difficult to monitor and control the students during the learning process. Also, the materials delivered are not maximal... so that it is difficult for students to understand the learning materials and usually it is also difficult for the students to do the tasks given).

Agreeing with R5's comments, R6 added that with online teaching it is difficult for the teacher to evaluate teaching and learning achievement and students' involvement, motoric skills, and attitudes. She said, '... sulit mengevaluasi hasil KBM, sulitnya memberikan penilaian kepada siswa, seperti penilaian keaktifan, motorik, serta sikap' (...difficult to evaluate teaching and learning attainment, and it is difficult to assess students' involvement, motoric skills, and attitudes). R3 related the constraints to unsupportive networks and surroundings. She said, '...jaringan yang bisa saja kurang stabil, dan fokus yang bisa saja terganggu dengan keadaan sekitar' (The network could be unstable, and the concentration could be bothered by the surrounding situation).

The third question was 'If you will have to teach online, what skills do you need to improve?' To this question, R2 responded that she needs to improve her knowledge of effective methods or strategies for online teaching. She said, '[Saya perlu meningkatkan] skills dalam menentukan kesesuaian metode atau strategi yang digunakan saat mengajar online yang mudah dipahami oleh pelajar' ([I need to improve my] skills in deciding methods or strategies suitable for online teaching that can make students understand easily). R4 needs to improve her teaching and learning management skills and online teaching strategies. She commented, 'Skill yang harus ditingkatkan berupa soft skill pengelolaan pembelajaran yang dapat menarik perhatian siswa baik berupa video dan animasi selain itu juga meningkatkan strategi pembelajaran maya seperti pembelajaran kelas nyata' (The skills that need to improve are soft skills such as the teaching and learning management that can attract student attention either in forms of video or animation, and online learning strategies that resemble real classroom learning strategies). R5 and R6 agreed on improving skills on how to use technology for online teaching. In a different vein, R1 and R3 said that they need to improve their speaking skills. R1 said, 'Menurut saya yang harus di tingkat kan ialah.. di speaking skill. Karena ketika belajar online.. siswa lebih meminta dan mengharapkan pengajarnya untuk lebih menjelaskan secara detail/rinci tentang materi yg akan di pelajari, dan juga ketika berbicara/mengajar harus jelas apa yg disampaikan' (In my opinion, the skill that needs to be improved is speaking skill. This is because when learning online, the students expect their teacher to explain the lesson in detail, and also the teacher has to be clear when speaking/delivering the materials).

\section{DISCUSSION}

The purposes of this study were to examine Indonesian EFL pre-service teachers' perceptions of their competencies for online language teaching and their perceptions of online language teaching. An important finding from the present study is that the majority of the participants had positive perceptions of their online language teaching competencies. As for the technological competencies, seven were rated ' $\mathrm{OK}$ ' by more than $40 \%$ of the participants, and three were rated 'Good'. These results somewhat contradict the results achieved in Champa et al.'s (2019) study, in which the teachers are beginner users in their competence level to use ICT in their teaching. Technological skills are related to the technical competencies of the teacher (Varvel, 2007). These include knowledge about how to use the software, synchronous and asynchronous tools, operating systems, learning systems and tools, and Web browsers, and how to implement security updates, the ability to troubleshoot technology issues, and the ability to assist learners effectively (Varvel, 2007; Darabi, Sikorski, \& Harvey, 2006), and the ability to create instructional websites and interactive learning environments (Young, 1997). The literature has highlighted that technological competencies have a strong impact on teacher readiness for online teaching. Findings of previous research demonstrated that the more familiar the teachers are with technology, such as a computer, internet, and media tools, the readier they are for teaching in an online environment.

On the contrary, there were two items in the technological aspects that were rated 'Poor' by more than $40 \%$ of the participants. The items were 'ability to construct interactive Web pages' $(44.07 \%)$ and 'ability to create basic Web 
pages' (40.68\%). In Compton's (2009) online teaching skill framework, these two skills are at the 'expert' and 'proficient' levels respectively. The literature has highlighted that teachers' knowledge of innovation such as web technology is an essential factor in embracing new technology (Krishnakumar \& Rajesh, 2011). Chapelle and Hegelheimer (2004) asserted that all $21^{\text {st }}$-century language teachers should be able to fix basic browser problems since almost all information will be retrieved through a browser boundary and have the expertise to create basic as well as interactive web pages.

Concerning the pedagogical aspects, among the highest-rated skills in the 'OK' and 'Good' categories by the participants were 'ability to facilitate communicative competence and online interaction' and 'creativity in using and adapting materials to create new online language materials and tasks to facilitate communicative competence and online interaction'. Goodyear, Salmon, Spector, Steeples, and Tickner (2001) emphasized the importance of teacher-student interaction and interpersonal communication in online courses. Teachers must be able to moderate, get involved in, and advance discussions to encourage student participation (Darabi et al., 2006) and they should employ various active, engaging, and effective communication techniques and formulate effective responses (Varvel, 2007).

A vast majority of the participants also rated their 'knowledge and ability to apply curriculum design framework for online language learning' as 'OK' and 'Good'. The knowledge and ability to apply the curriculum framework are important since learning a language online is different from learning a language in a traditional face-to-face context (Compton, 2009). This process entails planning instruction with course objectives, instructional strategies, activities, and assessments that are in line with the objectives (Varvel, 2007).

The results also showed that the participants had positive perceptions of their evaluation skills, in which the majority of the participants' responses also congregated in the 'OK' and 'Good' categories of the scale for all the six evaluation skills listed in the questionnaire. These results somewhat contradict the results achieved in Todd's (2020) study, in which the participants had problems with marking student assignments. According to Compton (2009), knowledge of online language learning tasks, software, and course evaluation is essential for online language teachers because a creative teacher would not be successful if "the learning tasks do not lead to the desired outcomes" (p. 85).

Despite the participants' positive perceptions of their competencies for online language teaching, the qualitative data showed that all the participants expressed their reluctance to teach online for a number of reasons such as unstable internet network, difficulties in delivering the materials, controlling and monitoring the students, as well as evaluating the learning process. Some of these perceived constraints were also revealed in several previous studies in different contexts of study (Todd, 2020; Dashtestani, 2013).

\section{CONCLUSION}

The purpose of this study was twofold: (1) to investigate Indonesian EFL pre-service teachers' perceptions of their technological, pedagogical, and evaluation skills in online language teaching, and (2) to explore their perceptions of online English language teaching. The results showed that the participants had positive perceptions of their online language teaching skills either in terms of technological, pedagogical, or evaluation competencies. The qualitative data however revealed that the participants would choose the face-to-face teaching rather than the online teaching format for a number of technical and classroom management issues.

Since the present study is rather narrow in scope, it is not likely to draw any perceptible conclusion for the field. However, the study has provided sufficient evidence to make several recommendations for further action. The EFL teacher training programs in Indonesian tertiary education institutions should provide training for pre-service teachers on online teaching, especially on pedagogical and evaluation skills. Besides training, pre-service teachers should be provided with first-hand experience of online language teaching, for example through the field teaching practice program, which is conducted online in place of face-to-face classroom teaching practice.

As with any research, the present study has some limitations. The first limitation is that the data were collected from only a small number of pre-service teachers doing the English major at an institution of higher education in Indonesia. The inclusion of more institutions from different geographical areas could increase the generalizability of the findings. Secondly, the data were collected only based on the participants' perceptions which were collected from pre-service teachers who had never had an experience of teaching English online. Collecting the data from the teachers who have already been involved in online language teaching could give more realistic results.

\section{RECOMMENDATIONS FOR FURTHER RESEARCH}

The present study provides an understanding of Indonesian EFL pre-service teachers' perceptions of their technological, pedagogical, and evaluation skills in online language teaching, and their perceptions of online English language teaching. It is recommended that educational researchers continue researching issues related to this field. It would be particularly useful if future research considers the limitation of the present study. Future research should involve a larger number of participants and include in-service teachers who have already had experiences in online English language teaching to allow more generalizable findings. 


\section{REFERENCES}

[1] Balanskat, A, Blamire, R, \& Kefala, S. (2006). The ICT impact report: A review of studies of ICT impact on schools in Europe, European Schoolnet, Brussels, Belgium, Retrieved January 5, 2021, from https://www.semanticscholar.org/paper/A-review-ofstudies-of-ICT-impact-on-schools-in-Balanskat-Blamire/3996392c75a6e01499c78a895a1c1429c89f13bd

[2] Baralt, M., Gurzynski-Weiss, L., \& Kim, Y. (2016). Engagement with the language: How examining learners' affective and social engagement explains successful learner-generated attention to form. In M. Sato \& S. Ballinger (Eds), Peer interaction and second language learning. Pedagogical potential and research agenda (pp. 209-240). John Benjamins.

[3] Champa, R, A., Rochsantiningsih, D., \& Kristiana, D. (2019). Teachers' readiness indicators on ICT integration into their teaching. Budapest International Research and Critics in Linguistics and Education (BirLE) Journal, 2(4), $195-203$. https://doi.org/10.33258/birle.v2i4.508

[4] Chapelle, C.A., \& Hegelheimer, V. (2004). The language teacher in the 21st century. In S. Fotos \& C. M. Browne (Eds.), New perspectives on CALL for second language classrooms (pp. 299-316). Lawrence Erlbaum Associates.

[5] Compton, L. (2009). Preparing language teachers to teach language online: A look at skills, roles, and responsibilities. Computer Assisted Language Learning, 22(1), 73-99. https://doi.org/10.1080/09588220802613831

[6] Darabi, A. A., Sikorski, E. G., \& Harvey, R. B. (2006). Validated competencies for distance teaching. Distance Education, 27(1), 105-122.

[7] Dashtestani, R. (2013). Implementing Mobile-Assisted Language Learning (MALL) in an EFL context: Iranian EFL teachers' perspectives on challenges and affordances. JALT CALL Journal, 9(2), 149-168.

[8] Dörnyei, Z. (2010). Questionnaires in second language research: Construction, administration, and processing (2nd ed.). Routledge.

[9] Downing, J. J., \& Dyment, J. E. (2013). Teacher educators' readiness, preparation, and perceptions of preparing preservice teachers in a fully online environment: An exploratory study. The Teacher Educator, 48(2), 96-109.

[10] Easton, S. S. (2003). Clarifying the instructor's role in online distance learning. Communication Education, 52(2), 87-105.

[11] Frese, J. C. (2006). A faculty development handbook for quality online instruction. [Doctoral dissertation]. Nova Southeastern University. Retrieved January 5, 2021, from https://nsuworks.nova.edu/cgi/viewcontent.cgi?article=1526\&context=gscis_etd

[12] Gay, G. H. (2016). An assessment of online instructor e-learning readiness before, during, and after course delivery. Journal of Computing in Higher Education, 28(2), 199-220.

[13] Goodyear, P., Salmon, G., Spector, J. M., Steeples, C., \& Tickner, S. (2001). Competences for online teaching: A special report. Educational Technology Research and Development, 49(1), 65-72.

[14] Grimshaw, J., Cardoso, W., \& Collins, L. (2017). Teacher perspectives on the integration of mobile-assisted language learning. In K. Borthwick, L. Bradley \& S. Thouësny (Eds.), CALL in a climate of change: Adapting to turbulent global conditions Short papers from EUROCALL (pp. 135-139). https://doi.org/10.14705/rpnet.2017.eurocall2017.702

[15] Hadiyanto, Mukminin, A., Makmur, Hidayat, M., \& Failasofah. (2013). Teaching in a digital era: English lecturers' readiness toward the internet use in teaching and learning at selected higher education institutions in Indonesia. Asia-Pacific Collaborative Education Journal, 9(2), 113-124.

[16] Hampel, R., \& Stickler, U. (2005). New skills for new classrooms: Training tutors to teach languages online. Computer Assisted Language Learning, 18(4), 311-326.

[17] Ivankova, N.V., Creswell, J.W., \& Stick, S.L. (2006). Using mixed-methods sequential explanatory design: From theory to practice. Field Methods, 18(1), 3-20. https://doi.org/10.1177/1525822X05282260

[18] Jaffee, D. (2003). Virtual transformation: Web-based technology and pedagogical change. Teaching Sociology, 31(2), $227-236$.

[19] Ko, S., \& Rossen, S. (2017). Teaching online: A practical guide. Routledge.

[20] Koehler, M. J., \& Mishra, P. (2005). What happens when teachers design educational technology? The development of technological pedagogical content knowledge. Journal of Educational Computing Research, 32(2), 131-152.

[21] Krishnakumar, R., \& Rajesh, K. M. (2011). Attitude of teachers of higher education towards e-learning. Journal of Education and Practice, 2(4), 48-54.

[22] Lamie, J. M. (2005). Evaluating change in English language teaching. Palgrave.

[23] Lichoro, D. M. (2015). Faculty preparedness for transition to teaching online courses in the Iowa Community College Online Consortium [Unpublished doctoral dissertation] Iowa State University. Retrieved September 3, 2020, from https://lib.dr.iastate.edu/cgi/viewcontent.cgi?article=5383\&context=etd

[24] Perifanou, M. Economides, A. A., \& Tzafilkou, K. (2021). Teachers' digital skills readiness during COVID-19 pandemic. International Journal of Emerging Technologies in Learning, 16(8), 238-251.

[25] Todd, R, W. (2020). Teachers' perceptions of the shift from the classroom to online teaching. International Journal of TESOL Studies, 2(2), 4-16. https://doi.org/10.46451/ijts.2020.09.02

[26] Townsend, M. B. (2017). Ipads in K-12 schools: A grounded theory study of value [Doctoral dissertation]. University of Phoenix. Retrieved October 31, 2021 from https://www.proquest.com/openview/4c968226219520d7032600df13d36619/1?pqorigsite $=$ gscholar $\& \mathrm{cbl}=18750 \&$ diss $=\mathrm{y}$

[27] Varvel, V. E. (2007). Master online teacher competencies. Online Journal of Distance Learning Administration, 10(1), 1-41.

[28] Ventayen, R. J. M. (2018). Teachers' readiness in online teaching environment: A case of department of education teachers. PSU Journal of Education, Management and Social Sciences, 2(1), 94-106.

[29] Williams, P. E. (2003). Roles and competencies for distance education programs in higher education institutions. The American Journal of Distance Education, 17(1), 45-57.

[30] Wray, M., Lowenthal, P. R., Bates, B., \& Stevens, E. (2008). Investigating perceptions of teaching online \& f2f. Academic Exchange Quarterly, 12(4), 243-248.

[31] Young, J. R. (1997). Rethinking the role of the professor in an age of high-tech tools. Chronicle of Higher Education, 44(6), 26-28. 


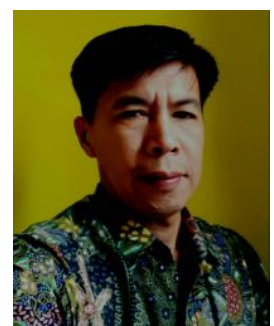

Daflizar was born in Kerinci, Indonesia in 1973. He obtained his Master's degree in TESOL and Ph.D. degree in Education (TESOL) from the University of Canberra, Australia. He is currently a senior lecturer at the English Education Department of Institut Agama Islam Negeri Kerinci, Jambi, Indonesia. His research interests include learner autonomy, language learning strategies, language teaching and learning, technologybased language learning, and language learning motivation.

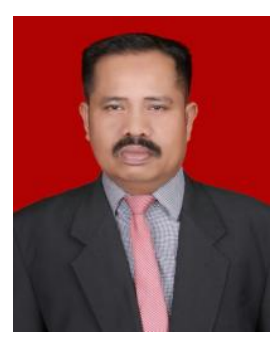

Toni Indrayadi is a lecturer and researcher at the English Education Department of Institut Agama Islam Negeri Kerinci, Jambi, Indonesia, and expert in research in English Language Teaching, Research Methodology, Speaking, and Pronunciation. He holds his Doctoral from Jambi University in English Education.

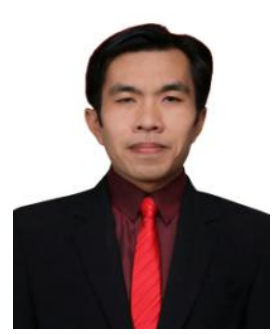

Yoki Irawan is an Assistant Professor and currently working as a lecturer at the English Education Department of Institut Agama Islam Negeri Kerinci, Jambi, Indonesia. He holds a magister degree in English Education from Universitas Negeri Padang (UNP), Padang, Indonesia. He has been teaching English to undergraduate students for the last 3 years. His areas of interest are TEFL, ESP, Curriculum and Material Development, and Systemic Functional Linguistics. 